Article

\title{
Housefly Pupae-Derived Antioxidant Peptides Exerting Neuroprotective Effects on Hydrogen Peroxide-Induced Oxidative Damage in PC12 Cells
}

\author{
Tingting Sun ${ }^{1,2}$, Sichen Zhang ${ }^{1,2}$, Wenzhe Yang ${ }^{2}$, Zhimin Zhao ${ }^{1,2}$ and Depo Yang ${ }^{1,2, *}$ \\ 1 School of Pharmaceutical Sciences, Sun Yat-sen University, Guangzhou 510006, China; \\ suntt8@mail2.sysu.edu.cn (T.S.); zhangsch3@mail2.sysu.edu.cn (S.Z.); zhaozhm2@mail.sysu.edu.cn (Z.Z.) \\ 2 Guangdong Technology Research Center for Advanced Chinese Medicine, Guangzhou 510006, China; \\ ywz19890409@sina.com \\ * Correspondence: 1ssydp@mail.sysu.edu.cn; Tel.: +86-020-3994-3043
}

Received: 12 November 2019; Accepted: 4 December 2019; Published: 7 December 2019

\begin{abstract}
In this study, two antioxidant peptides were identified and characterized from the alcalase-hydrolysate of housefly (Musca domestica L.) pupae guided by ABTS cation radical scavenging activity. Peptides sequences were identified as DFTPVCTTELGR (DR12, 1338.48 Da) and ARFEELCSDLFR (AR12, 1485.66 Da) using nano-liquid chromatography-tandem mass spectrometry (LC-MS/MS). Both DR12 and AR12 exert strong ABTS cation radical scavenging ability with $\mathrm{EC}_{50}$ values of 0.39 and $0.35 \mathrm{mM}$, respectively. Moreover, AR12 can effectively protect PC12 cells from oxidative damage induced by hydrogen peroxide $\left(\mathrm{H}_{2} \mathrm{O}_{2}\right)$ by decreasing intracellular reactive oxygen species (ROS) and malonaldehyde (MDA), recovering cellular mitochondrial membrane potential (MMP), and increasing the activity of intracellular superoxide dismutase (SOD). Stability tests suggest that AR12 is competent for the challenge of heating, acid, alkali or simulated gastrointestinal (GI) digestion and exhibits great activity to remove ABTS cation radical. DR12 shows a great stability against heating, but its antioxidative ability declines after being treated with acid, alkali or simulated GI digestion. In general, both DR12 and AR12 identified from housefly pupae hydrolysate stand a chance of being potential antioxidants or precursors to antioxidants and AR12 might be applied in the field of neuroprotection.
\end{abstract}

Keywords: housefly pupae; alcalase; antioxidant peptide; PC12 cells; neuroprotection

\section{Introduction}

Reactive oxygen species (ROS) are produced during cellular oxygen metabolism and play vital roles in vivo, such as inducing cell differentiation, proliferation and migration, and participating in inter- and intra-cellular signal transmission by stimulating glucose to be transported into cells [1]. However, when the body is suffering from fatigue or illness, the in vivo redox equilibrium could become disrupted, and the excessive accumulation of reactive species would lead to cellular oxidative stress and cause damage to various cellular components, such as membrane structures, DNA or proteins [2,3]. This is believed to be a primary cause or a secondary complication of various chronic diseases, e.g., cancer [4], diabetes [5], cardiovascular disease [6,7], rheumatoid arthritis [8], neurodegeneration, and aging process $[9,10]$.

In the last two decades, there has been a marked increase in searching for antioxidant peptides from food products, animals or plants resources [11] due to their higher safety and activity compared to synthetic antioxidants, such as butylated hydroxyanisole (BHA) and butylated hydroxytoluene (BHT) which are reported to have latent acute toxicity, developmental [12] and reproductive toxicity [13]. 
Various studies have verified that these peptides are usually encrypted in the parent proteins without activity until they are released by various means like fermentation, enzymatic hydrolysis, and curing. For example, Zhu et al. identified an antioxidant pentapeptide (Gly-Lys-Phe-Asn-Val) from Jinhua ham, a kind of traditional marinated meat, and this peptide exhibited great radical scavenging activity as well as $\mathrm{Fe}^{2+}$ chelating ability [14]. A survey conducted by Wang et al. reported that LQAEVEELRAALE from duck meat hydrolysate showed strong DPPH radical scavenging activity [15]. Three new antioxidant peptides (SVL, EAVQ, and RDY) purified from mulberry (Morus atropurpurea Roxb.) leaf neutrase-hydrolysates displayed great hemolysis inhibition ability and cellular antioxidant activity [16]. Many other researchers have identified various novel antioxidant peptides in edible marine fishes, shellfish, and their processing by-products $[17,18]$. It is obvious that natural antioxidant peptides have a promising future in the pharmaceutical industry, food applications, and cosmetics field due to their abundant raw materials, high efficiency, and high safety.

Housefly (Musca domestica L.) is one of the best-known economic insects with many features like strong reproductive capacity, high adaptability, saprophagous peculiarity and pathogenic resistance ability. Housefly larvae and pupae, namely "wuguchong" in traditional Chinese medicine, are rich in biomass with high-quality proteins, polyunsaturated fats, chitosan, vitamins, minerals and other nutrients [19]. It has been used for more than hundreds of years in clinical practice to treat gastrointestinal disease and heal wounds like malnutritional stagnation, damp-heat diarrhea, vomiting, decubital necrosis, ecthyma and lip boils [20,21]. Recently, there have been several studies focusing on the investigation of antioxidant activity of wuguchong and some progress has been made. For example, researchers isolated the polypeptides hydrolyzed by neutral protease from housefly larvae and the peptides showed great protective effect on hydrogen peroxide $\left(\mathrm{H}_{2} \mathrm{O}_{2}\right)$-induced oxidative damage in HepG2 cells [22]; He et al. verified that housefly larvae powder could prevent oxidative stress injury via regulation of UCP4 and CyclinD1 and modulation of JNK and P38 signaling in APP/PS1 mice [23]. However, most of these studies were conducted based on mixtures of peptides, and few specific housefly peptides exerting antioxidant activity have been reported in existing studies. Moreover, housefly pupa is also rich in biomass, protein accounting for more than $60 \%$ of dried pupa, and our previous study indicated that the peptides derived from housefly pupae show strong antioxidant activity [24], but the exploration of active components of housefly pupae is almost blank to date. Therefore, this study was aimed to explore the antioxidant peptides of housefly pupae.

Based on existing researches and the issues set forth above, this study was designed to purify and identify antioxidant peptides from alcalase-hydrolysate of housefly pupae. Firstly, guided by ABTS cation radical scavenging assay, housefly pupae hydrolysate $(\mathrm{HPH})$ was purified by cold acetone, ultrafiltration membranes with molecular weight cut-off (MWCO) of $10 \mathrm{kDa}$ and $3 \mathrm{kDa}$, size exclusion chromatography (SEC) and reversed-phased high-performance liquid chromatography (RP-HPLC) in sequence. The fraction with the best activity was identified using nano liquid chromatography-tandem mass spectrometry (LC-MS/MS) and then the peptides were synthesized by solid-phase reaction. Subsequently, the neuroprotective effect of the synthetic peptides on $\mathrm{H}_{2} \mathrm{O}_{2}$-induced oxidative damage in PC12 cells was explored. Finally, the stability of peptides under thermal, $\mathrm{pH}$ and simulated gastrointestinal (GI) digestion treatments was assessed (Figure 1). 


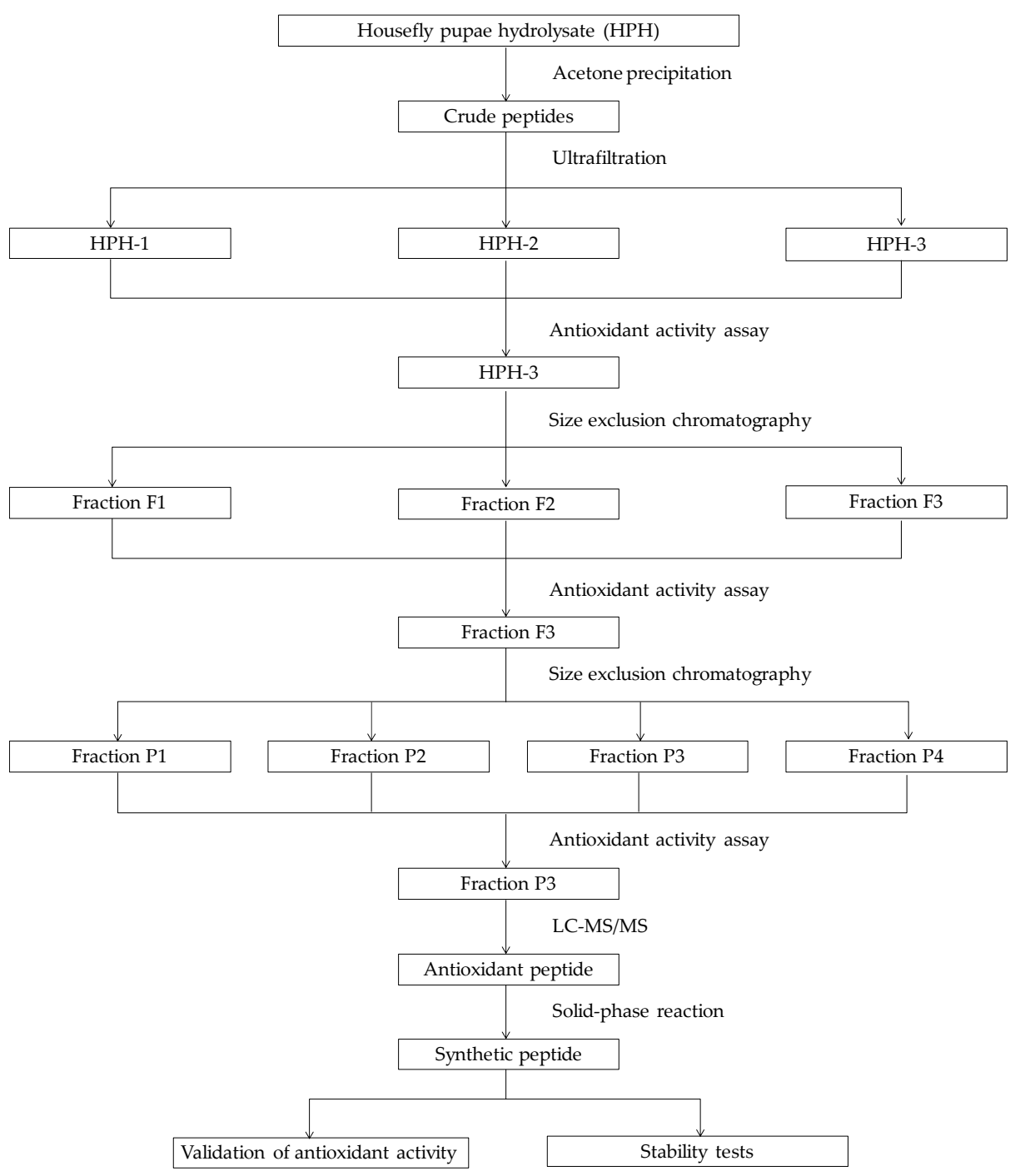

Figure 1. The schematic diagram for this study.

\section{Results and Discussion}

\subsection{Purification of Antioxidative Peptides}

Several studies have clarified the contribution of molecular size and structural characteristics to peptides bioactivity $[11,25]$. These studies showed that the number of amino acids of most antioxidant peptides liberated from parent proteins by enzymatic hydrolysis usually ranged from 2 to 20, and the potent antioxidant peptides were generally enriched in low molecular weight fractions $(<5 \mathrm{kDa})$. Ultrafiltration is a kind of membrane filtration to separate proteins according to molecular weight or concentration gradients under a certain amount of pressure [26].

In this study, the cold acetone-precipitated hydrolytic peptides were separated into three fractions (HPH-1, HPH-2 and HPH-3) with UF membranes with 3 and 10 kDa MWCOs. DPPH radical, ABTS cation radical and hydroxyl radical scavenging activities were used to evaluate the antioxidant capacities of each fraction. The results display that HPH-3 possesses higher radical scavenging ability than other fractions. In detail, the DPPH radical scavenging rate of $\mathrm{HPH}, \mathrm{HPH}-1, \mathrm{HPH}-2$ and $\mathrm{HPH}-3$ are $58.7 \pm 7.1 \%, 51.5 \pm 3.5 \%, 33.0 \pm 4.2 \%$ and $81.5 \pm 4.2 \%$ per $0.2 \mathrm{mg}$ peptide, respectively. The ABTS cation radical scavenging rate of the aforesaid four samples are $54.5 \pm 2.1 \%, 46.5 \pm 2.3 \%, 29.0 \pm 1.4 \%$ and $71.5 \pm 4.9 \%$ per $0.5 \mathrm{mg}$ peptide, respectively. The hydroxyl radical scavenging rate of the four samples are $49.0 \pm 1.7 \%, 45.5 \pm 2.1 \%, 24.5 \pm 0.7 \%$ and $61.6 \pm 3.8 \%$ per $2 \mathrm{mg}$ peptide, respectively (Figure $2 \mathrm{~A}, \mathrm{~B}$ ). 
Thus, according to the above results, antioxidant activities of the three fractions are HPH-3 $>\mathrm{HPH}-1>$ HPH-2 in descending order, it is obvious that the smallest fragment of molecular weight exhibits the best radical scavenging activity. However, it is also observed that the antioxidant activity does not show in descending molecular weight order. This result is slightly different from previous reports that the lower molecular size fraction had the higher antioxidant activities [19,26-28], but similar to the result reported by Wong et al. [27]. It could be conjectured that the peptides with lower molecular weight $(\mathrm{HPH}-3,<3 \mathrm{kDa})$ could react with free radicals much easier and convert them to more stable products and then terminate the radical chain reactions [29], which might make it clear that HPH-3 shows the best antioxidant activity. As for peptides with much higher molecular weight (HPH-1, $>10 \mathrm{kDa}$ ), they might contain more antioxidant activity sites compared to HPH-2 (3-10 kDa) that some sites could exhibit activity even in the parent protein. Therefore, according to the aforementioned results, HPH-3 with the best radical scavenging ability was chosen for further purification.

A

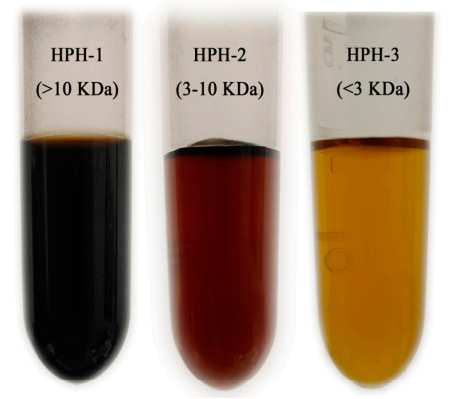

C

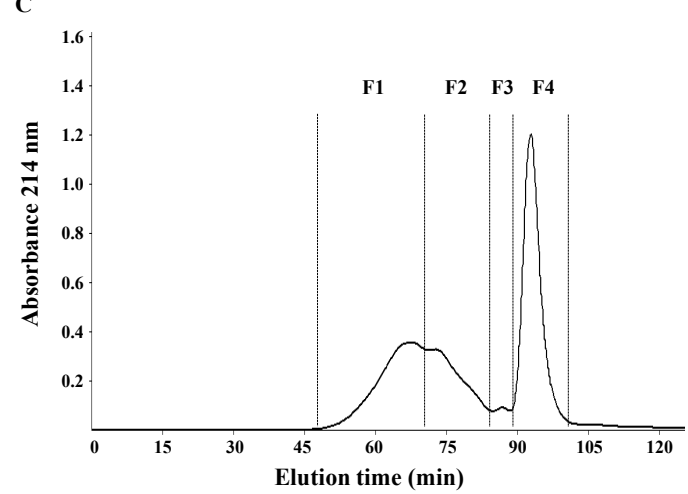

$\mathbf{E}$

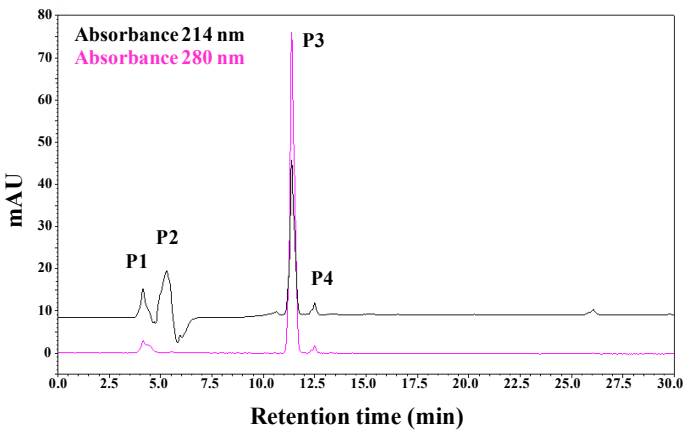

B

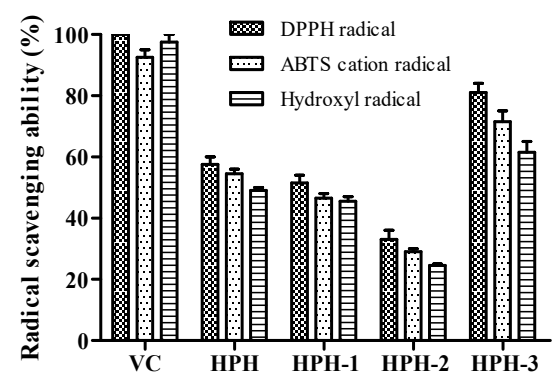

D

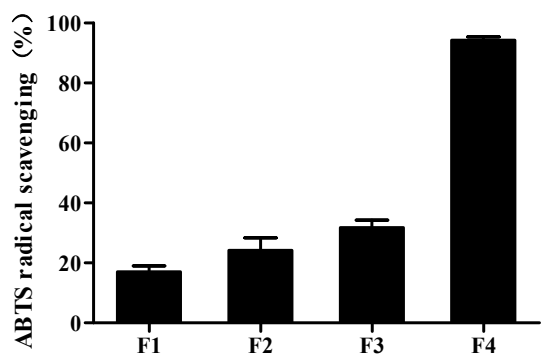

F

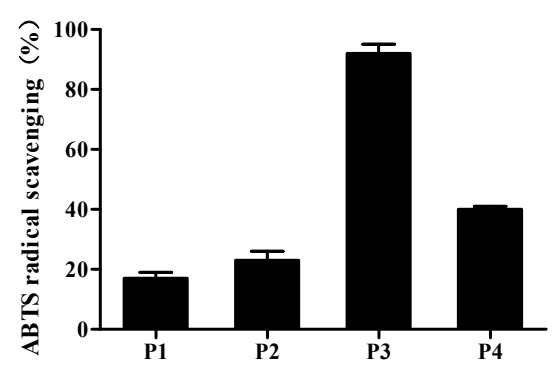

Figure 2. Antioxidant effects of peptide fractions separated from alcalase hydrolysate using UF, SEC and RP-HPLC. (A) Three fractions obtained using UF membranes with MWCO's of $10 \mathrm{kDa}$ and $3 \mathrm{kDa}$. (B) Effects of HPH-1, HPH-2 and HPH-3 ultrafiltration fractions on radical scavenging activity. (C) SEC chromatography profile of $<3 \mathrm{kDa}$ fraction. (D) Effects of F1, F2, F3 and F4 on ABTS cation radical scavenging activity. (E) RP-HPLC chromatography profile of F4 fraction. (F) Effects of P1, P2, P3 and $\mathrm{P} 4$ on ABTS cation radical scavenging activity. 
SEC is an efficient separation system on the basis of molecular size and widely applied to purify proteins and peptides, remove salt or exchange buffer of macromolecules solution [29]. As shown in Figure 2C, HPH-3 was fractionated into four subfractions (F1-F4), these subfractions were pooled according to their peak values and lyophilized to evaluate antioxidant activities. The result reveals that F4 has the highest ABTS cation radical scavenging ability $(89.2 \pm 1.1 \%$ per $0.2 \mathrm{mg}$ peptide), while the scavenging rate of the other three fractions were below $50 \%$ per $0.2 \mathrm{mg}$ peptide (Figure 2D).

F4 was further purified by RP-HPLC with a C18 column according to the structural properties of peptides, which is widely known as the final purification step due to its advantages of high sensitivity, resolution and column efficiency [30]. In general, large polar or hydrophilic peptides were eluted earlier, while the non-polar or hydrophobic peptides were eluted later. As displayed in Figure 2E, four peptide fractions (P1-P4) were obtained based on the elution time and concentrated in a rotary evaporator to evaluate their antioxidant activities. Among the four fractions, P3 with the retention time of 11.4 min shows the highest ABTS cation radical scavenging ability (Figure 2F), and the peak area accounts for $45.3 \%$ of the total peak area in the chromatogram at the absorbance $214 \mathrm{~nm}$. In consideration of the highest antioxidant activity and the great purity, $\mathrm{P} 3$ was chosen for determination of peptides and their amino sequence.

\subsection{Identification of Antioxidant Peptides}

Two peptides DFTPVCTTELGR (Asp-Phe-Thr-Pro-Val-Cys-Thr-Thr-Glu-Leu-Gly-Arg, DR12) and ARFEELCSDLFR (Ala-Arg-Phe-Glu-Glu-Leu-Cys-Ser-Asp-Leu-Phe-Arg, AR12) were identified from P3 (Figure 3A,B). Molecular weights of synthetic DR12 (1338.48 Da) and synthetic AR12 (1485.66 Da) were consistent with the theoretical masses of $1338.49 \mathrm{Da}$ and $1485.66 \mathrm{Da}$, respectively. Some studies have reported that DR12 is a part of peroxiredoxin 6 (Prx6) structure (42-53), which is an enzyme ubiquitously existing in life [31,32]. And several studies reported that AR12 is a part of heat shock proteins derived from human or dairy cows, respectively [33,34]. Although both of the sequence of DR12 and AR12 has been reported, their activities have not been characterized.

(A) DFTPVCTTELGR (DR12)

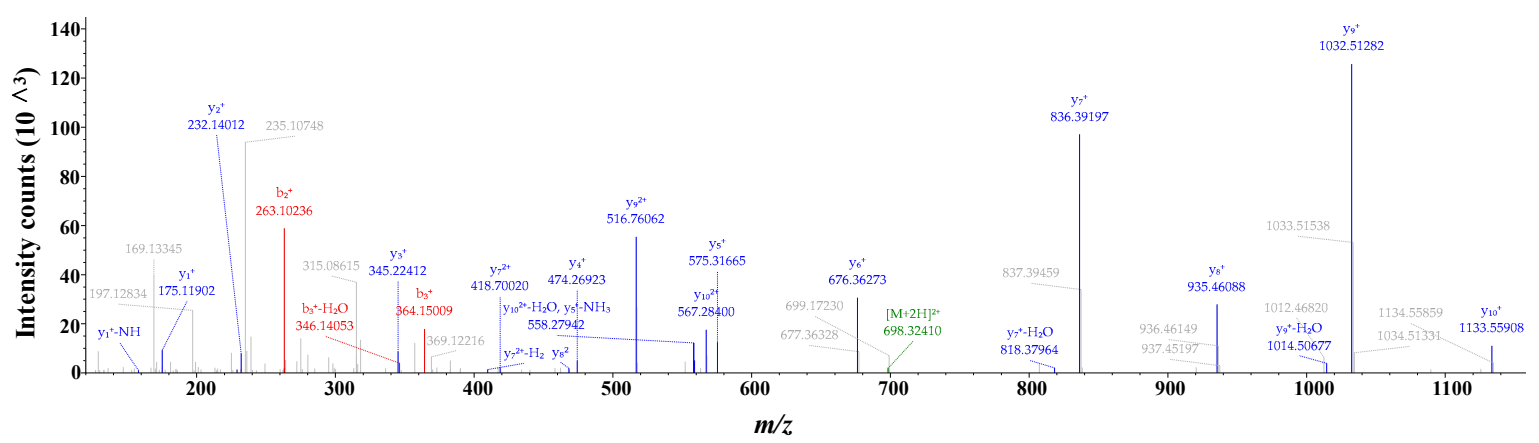

(B) ARFEELCSDLFR(AR12)

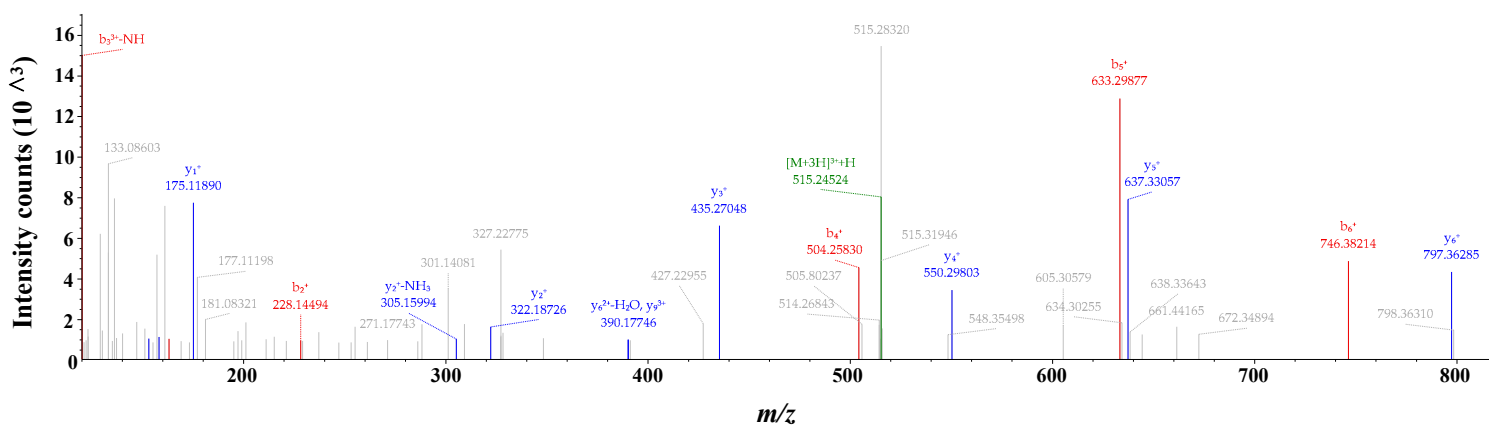

Figure 3. MS/MS spectra of the two peptides (A) DR12 and (B) AR12. 
Previous studies have reported that the antioxidant ability of peptides is closely associated with some structural characteristic of these peptides, such as their molecular weight, amino acid compositions and sequences [35,36]. These studies clarified that the peptides with appropriately low molecular weight and containing hydrophobic amino acids, aromatic amino acids or some special amino acids like Cys residue can exert stronger antioxidant activity. In accordance with these views, the molecular weights of two peptides we identified were both between $500 \mathrm{Da}$ to $1800 \mathrm{Da}$ [37]. Additionally, DR12 contains four hydrophobic amino acid residues (Phe, Pro, Val, Leu) and an antioxidant amino acid residue (Cys), among which, Phe is aromatic. Similar to the above results, AR12 contains five hydrophobic amino acid residues including Ala, Phe, and Leu, and also contains a Cys residue, Phe is an aromatic amino acid. Hydrophobicity of peptides plays a key role in exerting antioxidant ability in vivo. Depending on their hydrophobicity, these peptides could smoothly get through membrane lipid bilayers or directly interact with lipids to terminate lipid peroxidation [35]. Furthermore, Pro could enhance the hydroxyl radical scavenging ability of peptides due to a pyrrolidine ring in its structure as a proton donor and Cys contains a disulfide bond which makes it to be the most active antioxidant amino acid [35]. Thus, the structure profiles of DR12 and AR12 are also consistent with the previous statements that hydrophobic amino acids, aromatic amino acids, and some antioxidant amino acids could make a great contribution for the antioxidant ability of peptides.

\subsection{Neuroprotective Effect of Peptides on $\mathrm{H}_{2} \mathrm{O}_{2}$-Induced Cell Injury in PC-12 Cells}

PC12 cells were employed to evaluate the cytoprotective effect of DR12 and AR12 against oxidative stress-induced damage. First of all, PC12 cells were treated with various concentrations of peptides to evaluate their potential cytotoxic effect using MTT assay. The result displays that both DR12 and AR12 have no cytotoxic effect even when the concentration is up to $100 \mu \mathrm{M}$ (Figure 4B). Subsequently, the cells were dealt with different concentrations of $\mathrm{H}_{2} \mathrm{O}_{2}$ for $2 \mathrm{~h}$. As we can see in Figure $4 \mathrm{~A}$, as the concentration of $\mathrm{H}_{2} \mathrm{O}_{2}$ increased, cell vitality decreases linearly and drops to $47.9 \pm 2.3 \%$ when the concentration of $\mathrm{H}_{2} \mathrm{O}_{2}$ increases to $900 \mu \mathrm{M}$. In order to ensure that the effects of peptides could be better measured, $800 \mu \mathrm{M} \mathrm{H}_{2} \mathrm{O}_{2}$ was selected to induce oxidative damage of cells that there were at least half of viable cells. Figure 4C,D suggest that pretreatment with DR12 and AR12 could both recover the reduction of cells viability in a concentration-dependent manner, and AR12 shows better cytoprotective effect than DR12.

To further confirm the protective effect of AR12 against $\mathrm{H}_{2} \mathrm{O}_{2}$-induced cells injury, the percentage of cell apoptosis was measured by flow cytometry. In brief, the percentage of apoptotic cells induced by $300 \mu \mathrm{M} \mathrm{H}_{2} \mathrm{O}_{2}$ for $2 \mathrm{~h}$ is significantly increased from $5.2 \pm 0.8 \%$ to $34.4 \pm 3.3 \%$.

A

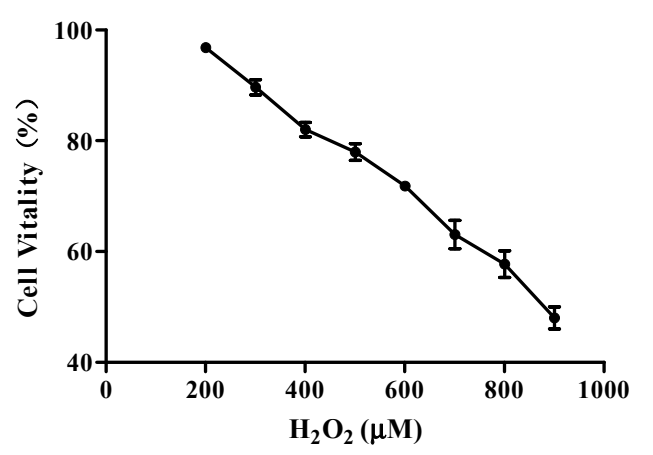

B

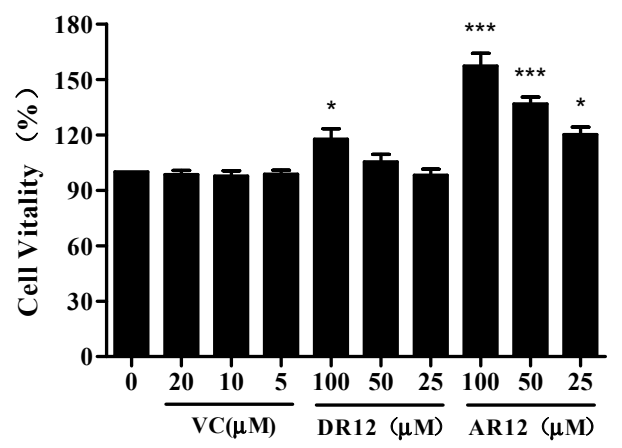

Figure 4. Cont. 

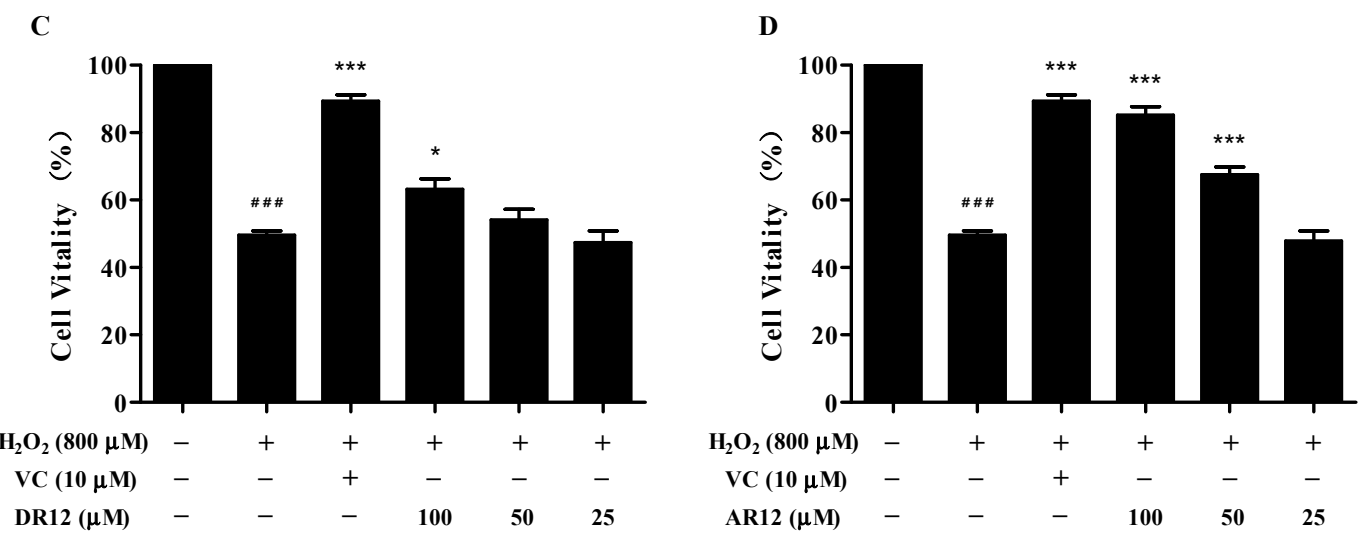

Figure 4. DR12 and AR12 protect PC12 cells against $\mathrm{H}_{2} \mathrm{O}_{2}$-induced cytotoxicity. (A) Cells were incubated with different concentrations of $\mathrm{H}_{2} \mathrm{O}_{2}(200-900 \mu \mathrm{M})$ for $2 \mathrm{~h}$, and then the effect of $\mathrm{H}_{2} \mathrm{O}_{2}$ on cell viability was detected. (B) Effect of DR12 and AR12 on PC12 cell viability. Cells were incubated with different concentrations of peptides $(25,50,100 \mu \mathrm{M})$ for $24 \mathrm{~h}$. (C,D) Effects of DR12 and AR12 (25, $50,100 \mu \mathrm{M})$ on PC12 cells against $\mathrm{H}_{2} \mathrm{O}_{2}$-induced cell death. Cells were pretreated with indicated doses of DR12 for $24 \mathrm{~h}$ and then treated with $800 \mu \mathrm{M} \mathrm{H}_{2} \mathrm{O}_{2}$ for $2 \mathrm{~h}$. VC $(10 \mu \mathrm{M})$ was used as a positive control. \#\#\# $P<0.001$ compared to control group. ${ }^{*} P<0.05$, ${ }^{* * *} P<0.001$ compared to model group.

Nevertheless, pretreatment with various concentrations of AR12 reduces cellular apoptosis to $21.9 \pm 1.1 \%, 12.1 \pm 1.6 \%$ and $8.2 \pm 2.8 \%$ in a dose-dependent manner (Figure 5 ). The above results indicate that the anti-apoptosis effect of AR12 could protect the PC12 cells from the damage induced by $\mathrm{H}_{2} \mathrm{O}_{2}$. However, DR12 shows little cellular anti-apoptosis effect under the same conditions.

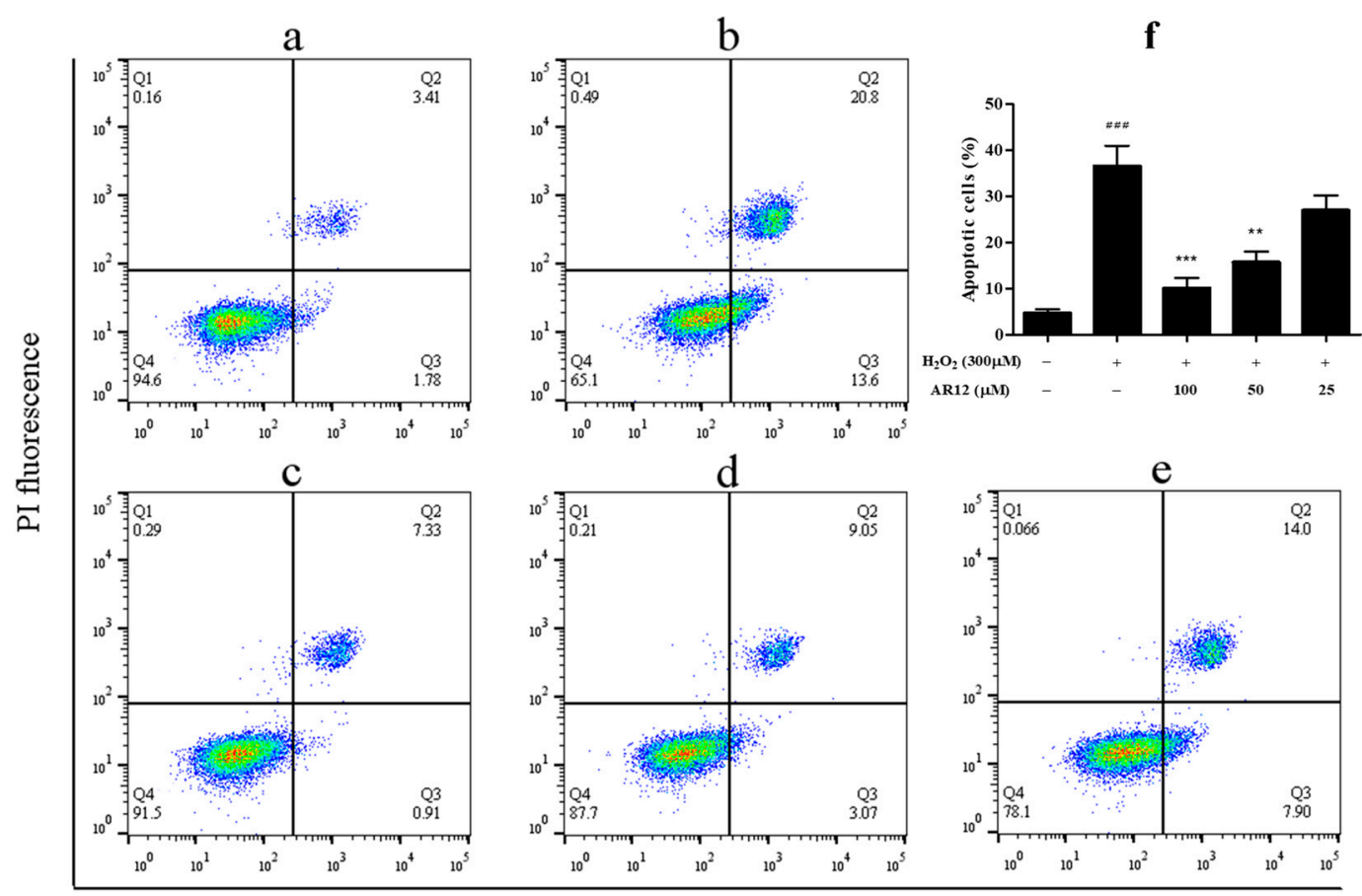

FITC fluorescence

Figure 5. Apoptosis of PC12 cells detected by flow cytometry. (a) Apoptosis of normal PC12 cells. (b) Apoptosis of the cells treated with $300 \mu \mathrm{M} \mathrm{H}_{2} \mathrm{O}_{2}$ for $2 \mathrm{~h}$. (c-e) Apoptosis of the cells that were pretreated with AR12 $(100,50,25 \mu \mathrm{M})$ for $24 \mathrm{~h}$ and then treated with $300 \mu \mathrm{M} \mathrm{H}_{2} \mathrm{O}_{2}$ for $2 \mathrm{~h}$. (f) Statistics of apoptosis rate of each group. ${ }^{\# \#} P<0.001$ compared to control group. ${ }^{* *} P<0.01,{ }^{* * *} P<0.001$ compared to model group. 


\subsection{AR12 Protected $\mathrm{H}_{2} \mathrm{O}_{2}$-Induced PC12 Cells Damage through Reducing Intracellular ROS}

As the products of intracellular oxygen metabolism, ROS participates in cells signaling and tissues injury that contributes to many diseases' progression, such as neurodegenerative diseases, aging process, and cardiovascular disease et al. [38]. Therefore, the level of intracellular ROS was detected in this study. As shown in Figure 6, intracellular ROS in PC12 cells bursts after incubation with $300 \mu \mathrm{M}$ $\mathrm{H}_{2} \mathrm{O}_{2}$ for $2 \mathrm{~h}$ (fluorescence intensity increased from $0.5 \pm 0.1 \%$ to $91.9 \pm 3.9 \%$ ). However, the oxidant burden of PC12 cells rapidly decreases in a dose-dependent manner after the pretreatment with various concentrations of AR12 for $24 \mathrm{~h}$. These results imply that $\mathrm{H}_{2} \mathrm{O}_{2}$-induced ROS accumulation in PC12 cells could be effectively antagonized by AR12.

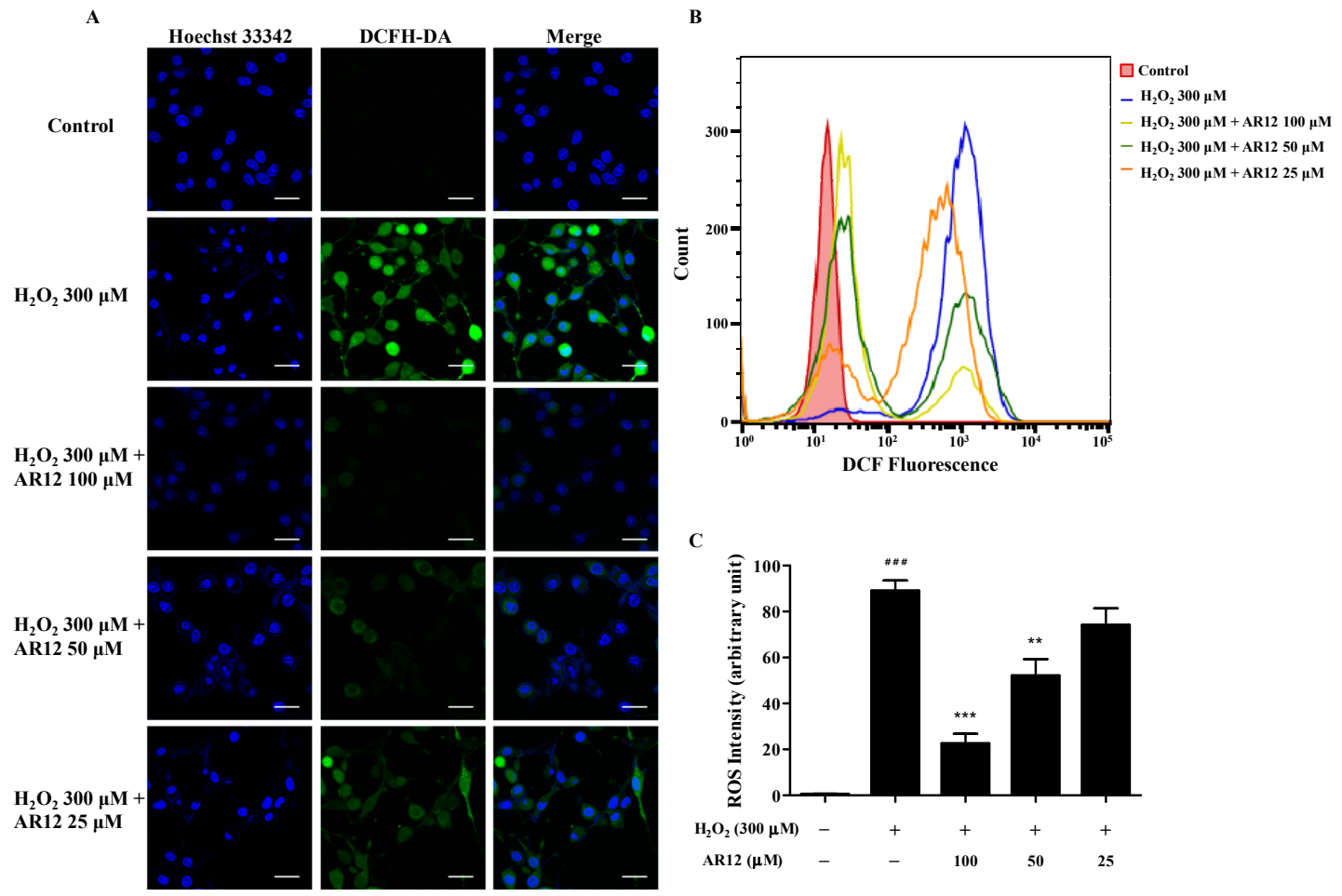

Figure 6. The ROS levels of PC12 cells. (A) The levels of ROS were observed by a confocal microscope with DCFH-DA as fluorescent probe. (B) The levels of ROS were detected by flow cytometry with DCFH-DA as fluorescent probe. (C) Statistics of ROS levels of each group. ${ }^{\# \# \# ~} P<0.001$ compared to control group. ${ }^{* *} P<0.01,{ }^{* * *} P<0.001$ compared to model group.

\subsection{AR12 Protected $\mathrm{H}_{2} \mathrm{O}_{2}$-Induced PC12 Cells Damage through Recovering the Loss of Mitochondrial} Membrane Potential (MMP)

Mitochondria play vital roles in various cellular biological processes, such as cell growth, cell cycle, apoptosis, and ROS generation. The function of mitochondria of cells could be indicated by MMP or mitochondrial morphology [10]. In order to determine the effect of AR12 on mitochondria of PC12 cells induced by $\mathrm{H}_{2} \mathrm{O}_{2}$, the MMP of PC12 cells treated with or without $\mathrm{H}_{2} \mathrm{O}_{2}$ or AR12 was detected by laser scanning confocal microscope. As displayed in Figure 7, exposure of cells to $\mathrm{H}_{2} \mathrm{O}_{2}$ leads to a sharp transformation of green fluorescence from red fluorescence, which indicates the collapse of MMP. While in AR12 pretreated groups, the intensity of green fluorescence is reduced in a dose-dependent manner, which suggests that AR12 is able to help recover the loss of cellular MMP to exert the neuroprotective effect. 


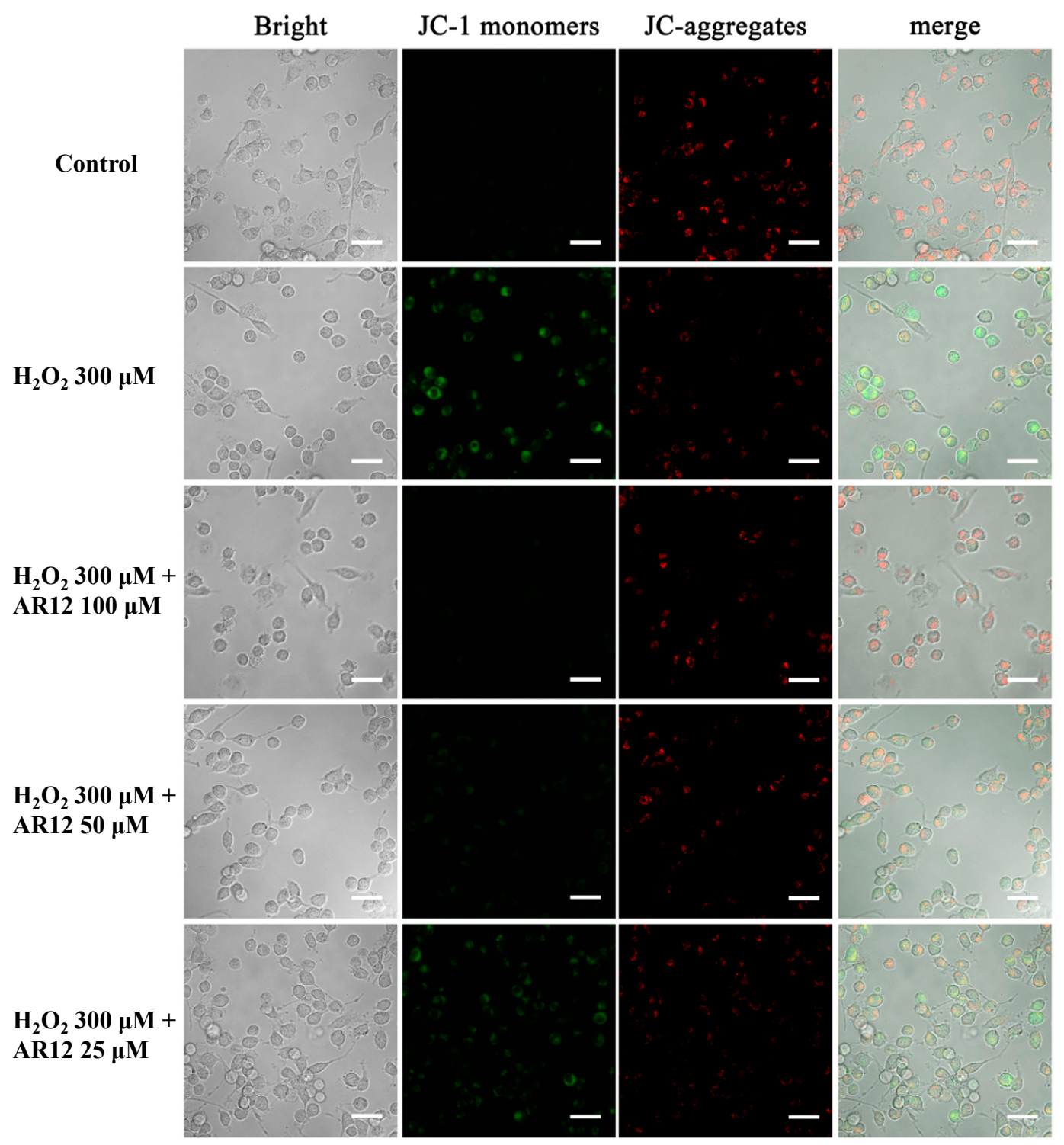

Figure 7. AR12 recovered the loss of MMP of PC12 induced by $\mathrm{H}_{2} \mathrm{O}_{2}$.

2.6. Effects of AR12 on Malonaldehyde (MDA) and Superoxide Dismutase (SOD) in $\mathrm{H}_{2} \mathrm{O}_{2}$-Induced PC12 Cells

As a product of lipid peroxidation, MDA is often regarded as a biomarker of oxidative stress. As expected, the MDA level in $\mathrm{H}_{2} \mathrm{O}_{2}$-induced cells significantly increase compared to control group, while the pretreatment with AR12 helps diminish the increase of MDA levels (Figure 8A).

There are many antioxidant defenses in organisms including enzymatic antioxidant defenses (SOD, glutathione peroxidase (GPx), catalase (CAT)) and non-enzymatic antioxidant defenses (ascorbic acid (vitamin C), a-tocopherol (vitamin E), glutathione (GSH)). These antioxidant defenses could maintain the redox balance in vivo under normal conditions [2]. In this study, the cellular SOD activity was tested using WST-8 assay. As shown in Figure 8B, SOD activities decrease in the $\mathrm{H}_{2} \mathrm{O}_{2}$-induced cells. However, treatment with AR12 attenuates the loss of cellular SOD activities in a dose-dependent manner. 

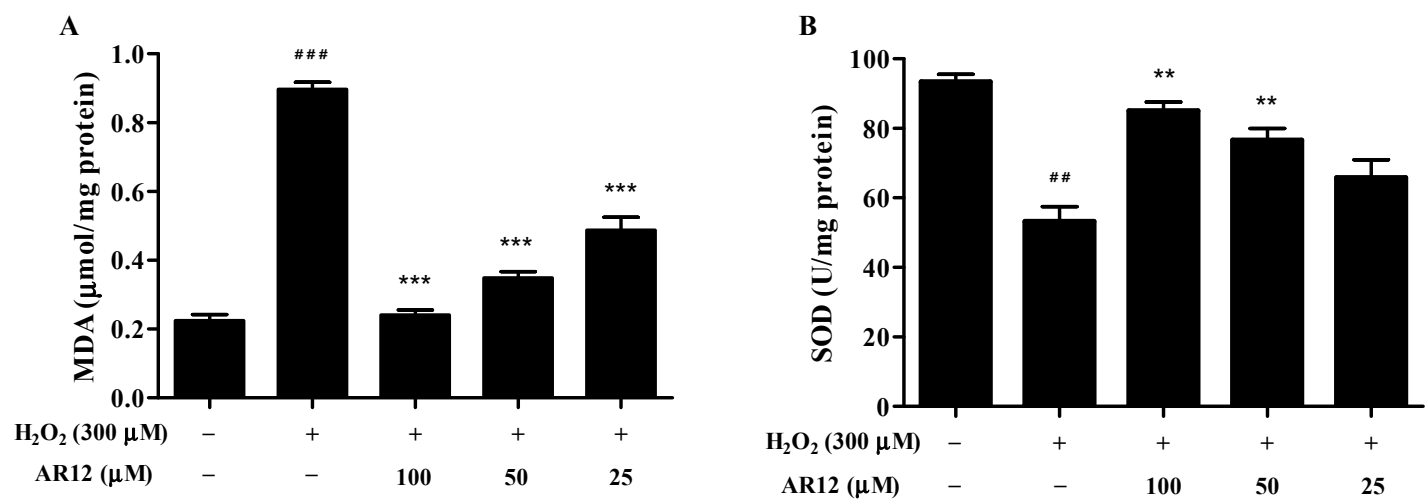

Figure 8. Effects of AR12 on MDA levels and SOD activities in $\mathrm{H}_{2} \mathrm{O}_{2}$-induced PC12 cells. Cells were pretreated with AR12 for $24 \mathrm{~h}$ and then treated with $300 \mu \mathrm{M} \mathrm{H}_{2} \mathrm{O}_{2}$ for $2 \mathrm{~h}$. (A) The MDA levels in $\mathrm{H}_{2} \mathrm{O}_{2}$-induced PC12 cells. (B) The SOD activities of $\mathrm{H}_{2} \mathrm{O}_{2}$-induced $\mathrm{PC} 12$ cells. ${ }^{\# \#} P<0.01,{ }^{\# \# \#} P<0.001$ compared to control group. ${ }^{* *} P<0.01,{ }^{* *} P<0.001$ compare to model group.

\subsection{Effects of Thermal, $p H$ and Simulated GI Digestion on Peptides}

Thermal stability of antioxidants is critical for their production, processing, and transportation process, namely, the property of inactivation at high temperature greatly prevents antioxidants from wider applications. As shown in Figure 9A, ABTS cation radical scavenging ability of DR12 incubated at $25,60,70,80,90^{\circ} \mathrm{C}$ almost keeps unchanged with $\mathrm{EC}_{50}$ values ranging from $0.36 \mathrm{mM}$ to $0.38 \mathrm{mM}$. In contrast, the influence of heating on AR12 depicted in Figure 9B reveals that AR12 is sensitive to high temperature. In detail, the ABTS cation radical scavenging ability of AR12 significantly increases as treated at 60,70 , and $80^{\circ} \mathrm{C}$, followed by a decline at $90^{\circ} \mathrm{C}$, the $\mathrm{EC}_{50}$ values are $0.24,0.23,0.27$, and $0.45 \mathrm{mM}$ (vs. $0.34 \mathrm{mM}$, treated at $25^{\circ} \mathrm{C}$ ), respectively. Theoretically, proteins after heat treatment would become denatured, condense, and then expose the hydrophobic domain. Additionally, hydrophobicity of peptides was reported to correlate with antioxidant properties. Therefore, it can be postulated that appropriately heating process could expose hydrophobic domain of AR12 and then make it easier to react with radicals. However, the excessive thermal treatment obviously destroys the active structure of AR12 that its ABTS cation radical scavenging ability significantly decreases after incubated at $90{ }^{\circ} \mathrm{C}$ compared with the untreated peptide. The aforementioned results suggest that both DR12 and AR12 could meet most heat treatment requirements, but excessive thermal process is not suitable for AR12. The influence of $\mathrm{pH}$ on peptides monitored by ABTS cation radical scavenging activity is displayed in Figure $9 \mathrm{C}, \mathrm{D}$. The $\mathrm{EC}_{50}$ values of DR12 markedly increase as $\mathrm{pH}$ below 3 or above 9 , which may be resulted from the changes of charge in DR12, particularly at $N$ - or $C$-terminal. However, AR12 displays favorable $\mathrm{pH}$ stability that the $\mathrm{EC}_{50}$ values range between 0.27 and $0.34 \mathrm{mM}$, interestingly, the ABTS cation radical scavenging ability of AR12 is always increased either in acidic or alkaline conditions. Both results of thermal and $\mathrm{pH}$ stability of AR12 could reveal that it can serve as a precursor for peptide with higher antioxidant activity.

Pepsin-pancreatin hydrolysis treatment was used to evaluate the effect of GI digestion on peptides (shown in Figure 9E,F). With $1 \mathrm{~h}$ of pepsin hydrolysis and $2 \mathrm{~h}$ of pancreatin hydrolysis at $37^{\circ} \mathrm{C}$, protease solution (pepsin and pancreatin) shows little activity to scavenge ABTS radical, DR12 has a slight decrease in ABTS radical scavenging ability by contrast to the activity of untreated peptide, which may be the result of degeneration of structure. However, AR12 shows great stability against the simulated GI digestion that there is no significant change in ABTS cation radical scavenging ability over the concentration change of AR12 between the untreated and treated peptide with $\mathrm{EC}_{50}$ values of 0.35 and $0.39 \mathrm{mM}$, respectively. 
(A) DR12

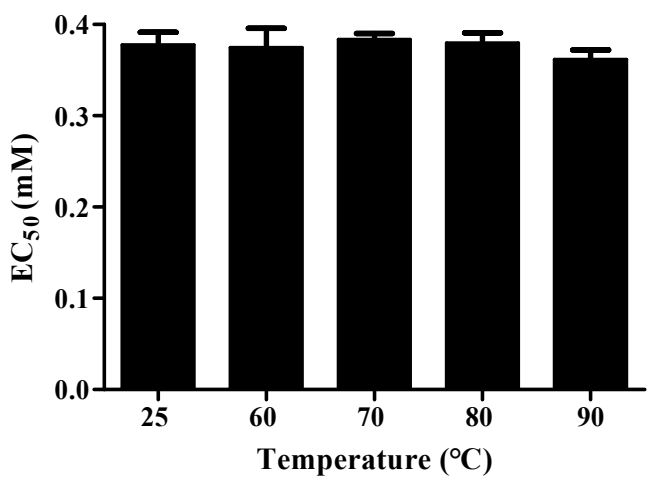

(C) DR12

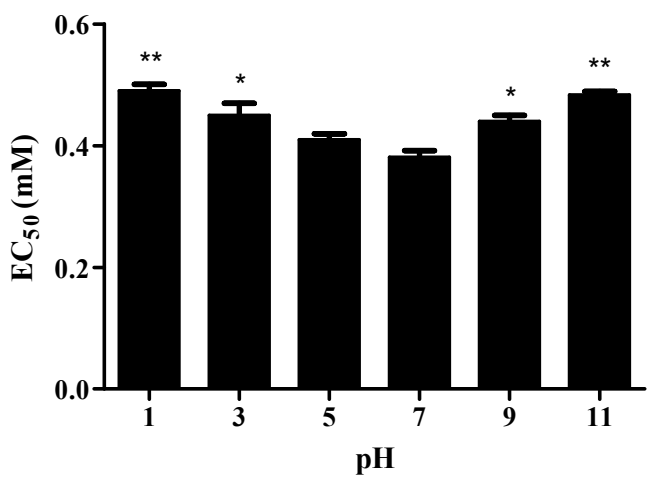

(E) DR12

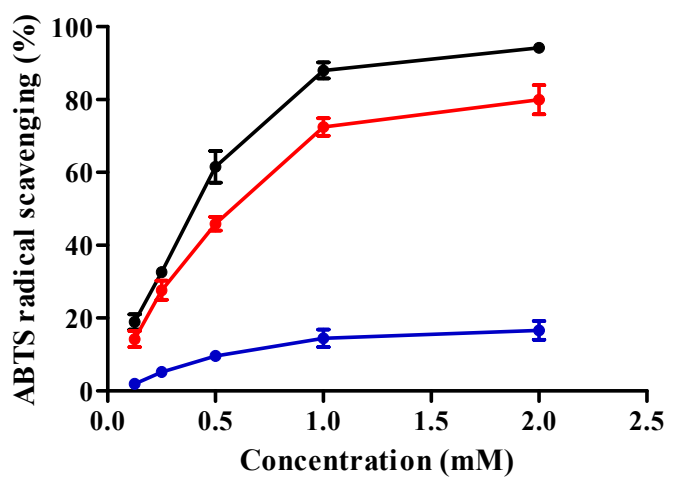

$\rightarrow$ DR12

$\rightarrow$ DR12 + pepsin + pancreatin

$\rightarrow$ pepsin + pancreatin
(B) AR12

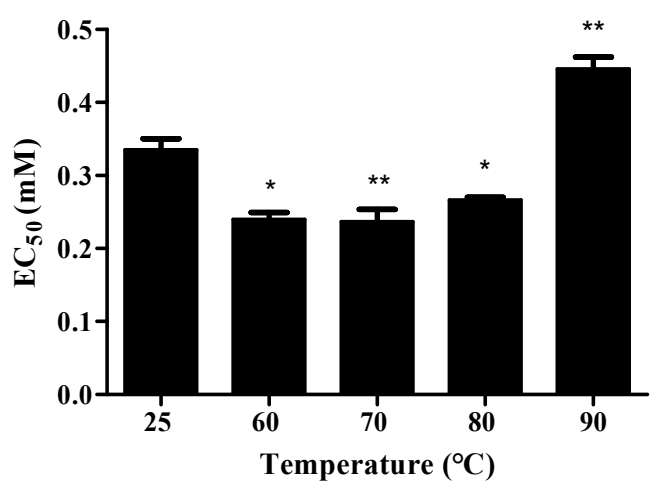

(D) AR12

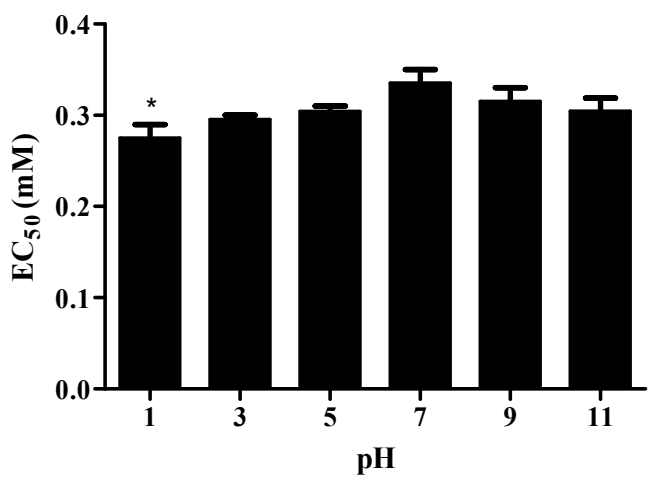

(F) AR12

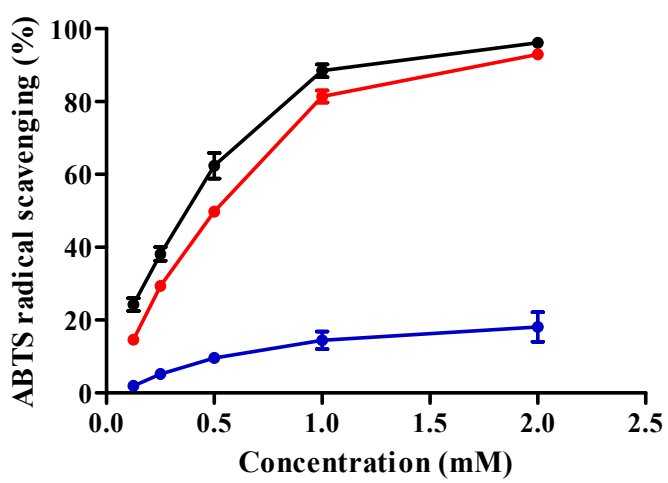

$\rightarrow$ AR12

$\rightarrow$ AR12 + pepsin + pancreatin

$\rightarrow$ pepsin + pancreatin

Figure 9. Stability tests of DR12 and AR12. (A,B) Effects of heating on DR12 and AR12. (C,D) Effects of $\mathrm{pH}$ on DR12 and AR12. (E,F) Effects of simulated GI digestion on DR12 and AR12. ${ }^{*} P<0.05,{ }^{* *} P<0.01$ compared to the group of $25^{\circ} \mathrm{C}$ or the group of $\mathrm{pH} 7$.

\section{Materials and Methods}

\subsection{Materials and Reagents}

Housefly (Musca domestica L.) pupae were obtained from Guangdong Magtech Bio-Technology Co., Ltd. (Guangzhou, China) and identified by Prof. Pang Hong from State Key Laboratory for Biocontrol and Institute of Entomology, Sun Yat-sen University. Ultrafiltration centrifugal units (MWCO of 3 and $10 \mathrm{kDa}$ ) were purchased from Merck (Darmstadt, Germany). Superdex 30 prep 
grade resins were purchased from GE Healthcare (Uppsala, Sweden). Acetonitrile (ACN) and trifluoroacetic acid (TFA) of HPLC grade were supplied by Macklin Biochemical Technology Co., Ltd. (Shanghai, China). 1,1-Diphenyl-2-picrylhydrazyl (DPPH), hydrogen peroxide $\left(\mathrm{H}_{2} \mathrm{O}_{2}, 30 \%\right.$, v/v, 3-(4, 5-dimethyl-2-thiazolyl)-2, 5-diphenyl-2- $\mathrm{H}$-tetrazolium bromide (MTT) and dimethyl sulfoxide (DMSO) were bought from Sigma-Aldrich (St. Louis, MO, USA). The differentiated rat pheochromocytoma (PC12) cell line was purchased from the Cell Bank of Shanghai Institute of Biochemistry and Cell Biology (Chinese Academy of Sciences, Shanghai, China). Roswell Park Memorial Institute (RPMI) 1640 Medium, fetal bovine serum (FBS), antibiotics (penicillin and streptomycin) and $0.25 \%$ trypsin-EDTA (phenol red) were bought from Gibco Life Technologies (Grand Island, NY, USA). Annexin V-FITC and propidium iodide (PI) Apoptosis Detection Kit was purchased from Becton, Dickinson and Company (BD, San Diego, CA, USA). Reactive Oxygen Species (ROS) Assay Kit, Mitochondrial Membrane Potential Assay Kit with JC-1, Total Malonaldehyde (MDA) Assay Kit, and Total Superoxide Dismutase (SOD) Assay Kit with WST-8 were purchased from Beyotime Biotechnology Co., Ltd. (Shanghai, China).

\subsection{Preparation of $\mathrm{HPH}$}

Housefly pupae were collected and washed with distilled water, and then oven-dried at $50{ }^{\circ} \mathrm{C}$ for 2 days. The dried pupae were crushed to 24-mesh powder, defatted with $n$-hexane in a Soxhlet apparatus at $50^{\circ} \mathrm{C}$ for $6 \mathrm{~h}$, and then the defatted pupae powder was suspended in distilled water $(w / v$, 1:20) by stirring at $4{ }^{\circ} \mathrm{C}$ for $30 \mathrm{~min}$ to extract proteins. Whereafter, the mixture was heated in boiling water $\left(100{ }^{\circ} \mathrm{C}\right)$ for $10 \mathrm{~min}$ to denature proteins. After cooling to $60^{\circ} \mathrm{C}$, the mixture was adjusted to $\mathrm{pH}$ 9.5. The hydrolysis reaction was conducted with alcalase amount of $6000 \mathrm{U} / \mathrm{g}$ at $60^{\circ} \mathrm{C}$ for $30 \mathrm{~min}$, following by heating to $100^{\circ} \mathrm{C}$ for $15 \mathrm{~min}$ to inactivate the alcalase. Finally, the mixture was centrifuged at $12,000 \times \mathrm{g}$ for $15 \mathrm{~min}$ and the supernatant $(\mathrm{HPH})$ was collected for further purification.

\subsection{Peptides Separation by Membrane Ultrafiltration}

4 -fold volume of cold acetone was added to $\mathrm{HPH}$ at $4{ }^{\circ} \mathrm{C}$ over the night to precipitate peptides, and then the resultant peptides were collected by centrifugation at $12,000 \times g$ for $15 \mathrm{~min}$. Finally, the crude peptides were lyophilized and kept at $4{ }^{\circ} \mathrm{C}$ for further use. The crude peptides were fractionated sequentially using ultrafiltration membranes with MWCO of $10 \mathrm{kDa}$ and $3 \mathrm{kDa}$ at $4700 \times g$ for $30 \mathrm{~min}$. The obtained three fractions (>10 kDa (HPH-1), 3-10 kDa (HPH-2), <3 kDa (HPH-3)) were freeze-dried and stored at $4{ }^{\circ} \mathrm{C}$. The fraction with the best radical scavenging activity was selected for further purification.

\subsection{Purification by Size Exclusion Chromatography}

HPH-3 was separated using a SEC column $(26 \mathrm{~mm} \times 60 \mathrm{~cm})$ packed with Superdex 30 prep grade (34 $\mu \mathrm{m}$, GE Healthcare Life Sciences). The column was equilibrated and eluted with $0.01 \mathrm{M}$ phosphate buffer $/ 0.15 \mathrm{M} \mathrm{NaCl}$ (pH 7.2). $1 \mathrm{~mL}$ of HPH-3 $(50 \mathrm{mg} / \mathrm{mL}$ in mobile phase) was loaded on the column and eluted at the flow-rate of $3 \mathrm{~mL} / \mathrm{min}$ at the room temperature and the monitoring absorbance was $214 \mathrm{~nm}$. All fractions were collected and lyophilized to measure the content of peptides with the o-phthaldialdehyde (OPA) method [39] and evaluate their ABTS cation radical scavenging activity.

\subsection{Purification by RP-HPLC}

The eluted fraction of SEC with the highest antioxidative activity was further purified by RP-HPLC on an Ultimate AQ-C18 column $(10 \times 250 \mathrm{~mm}, 5 \mu \mathrm{m}$, Welch, Shanghai, China). $200 \mu \mathrm{L}$ of F3 was injected and then eluted with a binary gradient where solvent $A$ was water containing $0.05 \%$ TFA and solvent $B$ was acetonitrile containing $0.05 \%$ TFA, the flow rate was set to $3 \mathrm{~mL} / \mathrm{min}$ and the elution profile was detected at $214 \mathrm{~nm}$ and $280 \mathrm{~nm}$. Gradient elution was performed as followed: $0-15 \%$ solvent B, $15 \mathrm{~min}$; $15-100 \%$ solvent B, $5 \mathrm{~min} ; 100 \%$ solvent B, $10 \mathrm{~min}$; and $100-0 \%$ solvent B, $10 \mathrm{~min}$. Eluted fractions were tested for ABTS cation radical scavenging activity. 


\subsection{Identification of Antioxidant Peptides by LC-MS/MS and Peptide Synthesis}

Purified peptides (P3) were identified on a Thermo EASY-nLC 1200 system coupled to a Thermo Q Exactive Plus Orbitrap LC-MS/MS system (Thermo Scientific, Waltham, Mass, USA). Briefly, the peptides desalted by MonoTip C18 column (C18 solid phase extraction disk, 3M Company, St. Paul, MN, USA) were redissolved in $0.1 \%$ formic acid and loaded on an analytical column $(75 \mu \mathrm{m} \times 30 \mathrm{~cm}$, ReproSil-Pur $120 \mathrm{C} 18-\mathrm{AQ}, 2 \mu \mathrm{m}$, Ammerbuch, Germany) under the constant pressure of $40 \mathrm{MPa}$. Eluent A was $0.1 \%$ formic acid aqueous solution and eluent B was acetonitrile/water/formic acid (80:20:0.1, v/v/v) solution, and then the gradient elution was performed at a flow rate of $200 \mathrm{~nL} / \mathrm{min}$, the elution program was as followed: $20-80 \%$ eluent B, $30 \mathrm{~min} ; 80-100 \%$ eluent B, $30 \mathrm{~min} ; 100 \%$ eluent B, 30 min. Mass spectrometry was performed with the positive ions electrospray scan mode (NSI source) and the scan range $m / z 350-1700$. The resolution of full MS was 70,000, and the resolution of the secondary mass was 35,000. Furthermore, the top ten most abundant doubly or multiply charged precursor ions in each MS scan were selected for fragmentation (MS2) by stepped higher energy collision dissociation (stepped HCD) of $25 \%$ around a normalized collision energy (NCE)-value of 20, 25, and 30. Thermo Scientific ${ }^{\mathrm{TM}}$ XCalibur ${ }^{\mathrm{TM}} 2.2$ software (Thermo Scientific, Waltham, Mass, USA) was used to analyze the mass spectrum and the Thermo Proteome Discoverer 2.2.0.388 software (Thermo Scientific, Waltham, Mass, USA was used for homology searches between the obtained sequences against the Musca Domestica proteome database from Uniprot. Peptides identified from HPH were synthesized via the solid-phase peptide procedure by Jier biochemical Co., Ltd. (Shanghai, China). The synthetic peptides were purified by RP-HPLC with a Kromasil C18 colume $(4.6 \times 250 \mathrm{~mm}, 5 \mu \mathrm{m})$, purity of more than $98 \%$, and the molecular weights were determined by LC/MS (LC/MS-2010 EV, Shimadzu, Kyoto, Japan).

\subsection{Radical Scavenging Activity Assay}

The DPPH radical scavenging activity of purified fractions was evaluated according to the published method with minor modifications [19]. Briefly, the sample group and blank group comprised $50 \mu \mathrm{L}$ of the sample solution or vehicle mixed with $50 \mu \mathrm{L}$ of $0.4 \mathrm{mM} \mathrm{DPPH}$; and the control group comprised $50 \mu \mathrm{L}$ of sample solution and $50 \mu \mathrm{L}$ of ethanol (the vehicle of DPPH radical). The reaction was performed in the dark for $30 \mathrm{~min}$. Subsequently, the scavenging of DPPH radical was determined by measuring the absorbance at $517 \mathrm{~nm}$ using a multifunctional microplate reader (FLUOstar Omega-ACU, BGM, Offenburg, Germany). The DPPH radical scavenging ability of the fractions was calculated according to the following equation:

$$
\text { DPPH radical scavenging activity }(\%)=\left[1-\left(A_{s}-A_{c}\right) / A_{b}\right] \times 100 \%
$$

where $A_{s}, A_{c}$ and $A_{b}$ represent the absorbance of the sample, control and blank groups, respectively. Ascorbic acid was used as a positive control.

The ABTS cation radical scavenging activity assay was conducted according to the manufacture instruction. $10 \mu \mathrm{L}$ of sample solution was added to $200 \mu \mathrm{L}$ of fresh ABTS working solution, and the reaction mixture was incubated in darkness for $10 \mathrm{~min}$, the absorbance was observed at $734 \mathrm{~nm}$. The ABTS cation radical scavenging activity was calculated by the following formula:

$$
\text { ABTS cation radical scavenging activity }(\%)=\left(1-A_{1} / A_{0}\right) \times 100 \%
$$

where $A_{1}$ and $A_{0}$ were the absorbances of sample group and control group, respectively. The sample solution of control group was replaced with deionized water. Ascorbic acid was used as a positive control.

The hydroxyl radical scavenging activity was determined on the basis of Zhou et al. [40] with some slight modifications. In simple terms, the reaction mixture contained $8 \mu \mathrm{L}$ of $18 \mathrm{mM}$ salicylic acid, $52 \mu \mathrm{L}$ of sample solution, and $8 \mu \mathrm{L}$ of $18 \mathrm{mM} \mathrm{FeSO}_{4}$, and then $32 \mu \mathrm{L}$ of $0.1 \% \mathrm{H}_{2} \mathrm{O}_{2}$ was subsequently 
added to the mixture to start the reaction. The absorbance was measured at $510 \mathrm{~nm}$, and the scavenging activity was calculated using the following formula:

$$
\text { hydroxyl radical scavenging activity }(\%)=\left[1-\left(A_{n}-A_{x}\right) / A_{m}\right] \times 100 \%
$$

where $A_{n}$ was the absorbance of the sample group, $A_{m}$ presented the absorbance of blank group that the sample solution was substituted by deionized water, and $A_{x}$ was the absorbance of control group that $\mathrm{FeSO}_{4}$ was replaced by deionized water. Ascorbic acid was used as a positive control.

\subsection{Cell Culture and Viability Analysis}

The PC12 cells (PC12 cells were purchased from the Cell Bank of Shanghai Institute of Biochemistry and Cell Biology (Chinese Academy of Sciences, Shanghai, China). were cultured in RPMI 1640 medium supplemented with $10 \%$ FBS and $1 \%$ penicillin and streptomycin in a humid atmosphere of $5 \% \mathrm{CO}_{2}$ at $37^{\circ} \mathrm{C}$.

PC12 cells were seeded at $5 \times 10^{3}$ cells/well in a 96-well plate for $24 \mathrm{~h}$, and then the cells were pretreated with various concentrations $(100,50,25 \mu \mathrm{M})$ of peptides for $24 \mathrm{~h}$. The medium was discarded and $\mathrm{H}_{2} \mathrm{O}_{2}(200-900 \mu \mathrm{M})$ was added to stimulate cells damage. After $2 \mathrm{~h}, 10 \mu \mathrm{L}$ of $5 \mathrm{mg} / \mathrm{mL}$ MTT was added to each well and the cells were incubated for $4 \mathrm{~h}$ at $37^{\circ} \mathrm{C}$ in the dark. Subsequently, the supernatant was removed and $100 \mu \mathrm{L}$ of DMSO was added to dissolve the dark blue formazan crystals formed in intact cells, and the absorbance at $495 \mathrm{~nm}$ was measured with a microplate reader.

\subsection{Apoptosis Assay}

Apoptosis was assessed using the Annexin V-FITC and propidium iodide (PI) Detection Kit (BD) and detected by flow cytometer (Guava easyCyte, Millipore, Darmstadt, Germany) following the instructions of the manufacturer. Briefly, PC12 cells were seeded at $1 \times 10^{5}$ cells/well in a 12-well plate for $24 \mathrm{~h}$ and pretreated with various concentrations $(100,50,25 \mu \mathrm{M})$ of peptides for another $24 \mathrm{~h}$, following by treatment of $300 \mu \mathrm{M} \mathrm{H}_{2} \mathrm{O}_{2}$ for $2 \mathrm{~h}$. After the stimulation, the cells were harvested and washed with $1 \times$ phosphate buffer saline (PBS) and resuspended in $1 \times$ binding buffer, and then stained with Annexin V-FITC and PI for 15 min before detection. The analysis was done with FlowJo V10 software (BD, San Diego, CA, USA).

\subsection{Intracellular ROS Level Measurement}

ROS production in PC12 cells were detected with DCFH-DA by a laser scanning confocal microscope (FV 3000, Olympus, Tokyo, Japan) and a flow cytometry. DCFH-DA could be hydrolyzed by intracellular esterases and turns to be $2^{\prime}, 7^{\prime}$-dichlorofluorescin (DCF) with high fluorescence upon the oxidation by ROS. After drug treatment, the cells were incubated with $10 \mu \mathrm{M}$ DCFH-DA in FBS-free medium at $37^{\circ} \mathrm{C}$ for $20 \mathrm{~min}$, and then the medium was aspirated and cells were washed twice with FBS-free medium. Finally, the images of cellular DCF fluorescence intensities were analyzed with FV31S-SW software and the quantitative analysis of fluorescence intensities were analyzed with FlowJo V10 software.

\subsection{Measurement of MMP}

MMP of PC12 cells was determined using JC-1 which could aggregate in mitochondrial matrix and formed J-aggregates with red fluorescence when the MMP was at a high state. In contrast, when MMP was at a low state, JC-1could not aggregate but existed as a monomer with green fluorescence. At the end of the proper treatment, the cells were incubated with JC- 1 in buffer solution at $37^{\circ} \mathrm{C}$ for 20 min and washed twice with FBS-free medium. The fluorescence intensities of PC12 cells were analyzed by laser scanning confocal microscope. 


\subsection{Measurement of Intracellular MDA Content and SOD Activity}

The content of intracellular MDA and the SOD activity of PC12 cells were measured according to the manufacturer instructions. Briefly, after treatment, the cells were lysed and collected on ice. Subsequently, the cell lysate was centrifuged at $12,000 \times g$ at $4{ }^{\circ} \mathrm{C}$ for $5 \mathrm{~min}$ and the supernatants were collected. Protein concentrations of samples were determined by BCA assay. The absorbances of detecting MDA and SOD were respectively read at 532, $450 \mathrm{~nm}$ in a microplate reader. The MDA content was expressed in micromoles per mg protein, and SOD activities were expressed as units per mg of total protein.

\subsection{Stability of Synthetic Peptides against Heat, $p H$, and Simulated GI Digestion}

Thermal stability of synthetic peptides was determined according to the method of Yarnpakdee et al. [41] with minor modifications. The synthetic peptides were respectively incubated at $25,60,70,80,90^{\circ} \mathrm{C}$ for $30 \mathrm{~min}$ and then measured their scavenging ability of ABTS cation radical. The ability of synthetic peptides against $\mathrm{pH}$ treatments was measured according to Zhu et al. [42]. In brief, $\mathrm{pH}$ of peptide solution was adjusted to $1,3,5,7,9,11$, incubated at room temperature for $1 \mathrm{~h}$, and then ABTS cation radical scavenging activity of the treated peptides was measured. A two-stage digestion of protease in vitro (pepsin-digestion for $1 \mathrm{~h}$ and then pancreatin-digestion for $2 \mathrm{~h}$ at $37^{\circ} \mathrm{C}$ ) was performed as described by Zhang et al. [43]. The ABTS cation radical scavenging ability was evaluated to assess the peptides stability against GI digestion.

\subsection{Statistical Analysis}

All the experiments were performed in triplicate and results were expressed as means \pm SD. Statistical evaluation was performed using one-way ANOVA with the GraphPad Prism 5 software (GraphPad Software, San Diego, CA, USA). $P<0.05$ was considered to be statistically significant.

\section{Conclusions}

In this study, two antioxidant peptides (DR12 and AR12) were purified and identified from housefly pupae hydrolysate. Both peptides exhibited potent antioxidant activity to remove the various radicals and neuroprotective capacity against $\mathrm{H}_{2} \mathrm{O}_{2}$ induced oxidative stress damage in PC12 cells, and AR12 can significantly decrease intracellular ROS and MDA content, recover cellular MMP, increase the activity of intracellular SOD, and further protect PC12 cells against $\mathrm{H}_{2} \mathrm{O}_{2}$-induced apoptosis and oxidative injury. In addition, antioxidant activity of DR12 is stable against thermal treatments but decreases when treated by acid and alkali, or by GI digestion. AR12 exerts much better ability to remove ABTS cation radical when treated by heating or adjusted to $\mathrm{pH}$ acidic and alkaline, besides, AR12 shows great stability against GI digestion. Overall, both peptides have a chance to be potential antioxidants or precursors to antioxidants, and AR12 might be applied in the field of neuroprotection. All of the results above provide sufficient evidences for the further exploration of antioxidant activity of housefly pupae.

Author Contributions: Conceptualization, T.S.; methodology, T.S.; software, T.S.; validation, T.S. and S.Z.; formal analysis, T.S.; investigation, T.S., S.Z. and W.Y.; resources, W.Y.; data curation, Z.Z.; writing-original draft preparation, T.S.; writing-review and editing, T.S., S.Z., Z.Z. and D.Y.; visualization, T.S.; supervision, D.Y.; project administration, D.Y.; funding acquisition, D.Y.

Funding: This work was funded by the International Program for Ph.D. Candidates from Sun Yat-Sen University, Guangdong Provincial Department of Science and Technology, Grant number 2011B010700098, and Program for New Century Excellent Talents in University, Grant number NECT-12-0675.

Acknowledgments: Yang De-zhi, Yang Wen-zhe, from Guangdong Magtech Bio-Technology Co., Ltd., Dongguan Guangdong Provence, People's Republic of China, are greatly appreciated for their assistance in housefly larva rearing. 
Conflicts of Interest: The authors declare no conflict of interest. The funders had no role in the design of the study; in the collection, analyses, or interpretation of data; in the writing of the manuscript, or in the decision to publish the results.

\section{References}

1. Mirończuk-Chodakowska, I.; Witkowska, A.M.; Zujko, M.E. Endogenous non-enzymatic antioxidants in the human body. Adv. Med. Sci. 2018, 63, 68-78. [CrossRef] [PubMed]

2. Valko, M.; Leibfritz, D.; Moncol, J.; Cronin, M.T.D.; Mazur, M.; Telser, J. Free radicals and antioxidants in normal physiological functions and human disease. Int. J. Biochem. Cell Biol. 2007, 39, 44-84. [CrossRef] [PubMed]

3. Dröge, W. Free Radicals in the Physiological Control of Cell Function. Physiol. Rev. 2002, 82, 47-95. [CrossRef] [PubMed]

4. Gęgotek, A.; Nikliński, J.; Žarković, N.; Žarković, K.; Waeg, G.; Łuczaj, W.; Charkiewicz, R.; Skrzydlewska, E. Lipid mediators involved in the oxidative stress and antioxidant defence of human lung cancer cells. Redox Biol. 2016, 9, 210-219. [CrossRef]

5. Zujko, M.E.; Witkowska, A.M.; Górska, M.; Wilk, J.; Kretowski, A. Reduced intake of dietary antioxidants can impair antioxidant status in type 2 diabetes patients. Pol. Arch. Med. Wewn. 2014, 124, 599-607. [CrossRef]

6. Lakshmi, S.V.V.; Padmaja, G.; Kuppusamy, P.; Kutala, V.K. Oxidative stress in cardiovascular disease. Indian J. Biochem. Biophys. 2009, 46, 421-440.

7. Lammi, C.; Aiello, G.; Boschin, G.; Arnoldi, A. Multifunctional peptides for the prevention of cardiovascular disease: A new concept in the area of bioactive food-derived peptides. J. Funct. Foods 2019, 55, 135-145. [CrossRef]

8. Ghavipour, M.; Sotoudeh, G.; Tavakoli, E.; Mowla, K.; Hasanzadeh, J.; Mazloom, Z. Pomegranate extract alleviates disease activity and some blood biomarkers of inflammation and oxidative stress in Rheumatoid Arthritis patients. Eur. J. Clin. Nutr. 2017, 71, 92-96. [CrossRef]

9. Angelova, P.R.; Abramov, A.Y. Role of mitochondrial ROS in the brain: From physiology to neurodegeneration. FEBS Lett. 2018, 592, 692-702. [CrossRef]

10. Zhao, X.Y.; Lu, M.H.; Yuan, D.J.; Xu, D.E.; Yao, P.P.; Ji, W.L.; Chen, H.; Liu, W.L.; Yan, C.X.; Xia, Y.Y.; et al. Mitochondrial dysfunction in neural injury. Front. Neurosci. 2019, 13, 1-14. [CrossRef]

11. Chai, T.T.; Law, Y.C.; Wong, F.C.; Kim, S.K. Enzyme-Assisted discovery of antioxidant peptides from edible marine invertebrates: A review. Mar. Drugs 2017, 15, 42. [CrossRef] [PubMed]

12. Yang, X.; Sun, Z.; Wang, W.; Zhou, Q.; Shi, G.; Wei, F.; Jiang, G. Developmental toxicity of synthetic phenolic antioxidants to the early life stage of zebrafish. Sci. Total Environ. 2018, 643, 559-568. [CrossRef] [PubMed]

13. Ham, J.; Lim, W.; Park, S.; Bae, H.; You, S.; Song, G. Synthetic phenolic antioxidant propyl gallate induces male infertility through disruption of calcium homeostasis and mitochondrial function. Environ. Pollut. 2019, 248, 845-856. [CrossRef] [PubMed]

14. Zhu, C.Z.; Zhang, W.G.; Zhou, G.H.; Xu, X.L.; Kang, Z.L.; Yin, Y. Isolation and identification of antioxidant peptides from Jinhua ham. J. Agric. Food Chem. 2013, 61, 1265-1271. [CrossRef] [PubMed]

15. Wang, L.S.; Huang, J.C.; Chen, Y.L.; Huang, M.; Zhou, G.H. Identification and Characterization of Antioxidant Peptides from Enzymatic Hydrolysates of Duck Meat. J. Agric. Food Chem. 2015, 63, 3437-3444. [CrossRef]

16. Sun, C.; Tang, X.; Ren, Y.; Wang, E.; Shi, L.; Wu, X.; Wu, H. Novel Antioxidant Peptides Purified from Mulberry (Morus atropurpurea Roxb.) Leaf Protein Hydrolysates with Hemolysis Inhibition Ability and Cellular Antioxidant Activity. J. Agric. Food Chem. 2019, 67, 7650-7659. [CrossRef]

17. Chai, T.T.; Tong, S.R.; Law, Y.C.; Ismail, N.I.M.; Manan, F.A.; Wong, F.C. Anti-Oxidative, metal chelating and radical scavenging effects of protein hydrolysates from blue-spotted stingray. Trop. J. Pharm. Res. 2015, 14, 1349-1355. [CrossRef]

18. Qian, Z.J.; Jung, W.K.; Byun, H.G.; Kim, S.K. Protective effect of an antioxidative peptide purified from gastrointestinal digests of oyster, Crassostrea gigas against free radical induced DNA damage. Bioresour. Technol. 2008, 99, 3365-3371. [CrossRef]

19. Zhao, S.; Cheng, Q.; Peng, Q.; Yu, X.; Yin, X.; Liang, M.; Ma, C.W.; Huang, Z.; Jia, W. Antioxidant peptides derived from the hydrolyzate of purple sea urchin (Strongylocentrotus nudus) gonad alleviate oxidative stress in Caenorhabditis elegans. J. Funct. Foods 2018, 48, 594-604. [CrossRef] 
20. Ai, H.; Wang, F.; Xia, Y.; Chen, X.; Lei, C. Antioxidant, antifungal and antiviral activities of chitosan from the larvae of housefly, Musca domestica L. Food Chem. 2012, 132, 493-498. [CrossRef]

21. Shen, J.; Chen, J.; Yang, D.; Zhao, Z.; Tang, C.; Zhang, R.; Yang, W.; Niu, Y. Antidiarrheal effects of a thermostable protein fraction obtained from the larvae of Musca domestica. Biomed. Pharmacother. 2019, 115, 108813. [CrossRef] [PubMed]

22. Zhu, L.; Wang, P.; Qin, Q.; Zhang, H.; Wu, Y. Protective effect of polypeptides from larva of housefly (Musca domestica) on hydrogen peroxide-induced oxidative damage in HepG2 cells. Food Chem. Toxicol. 2013, 60, 385-390. [CrossRef] [PubMed]

23. He, Y.; Yang, X.; Jiao, M.; Anoopkumar-Dukie, S.; Zeng, Y.; Mei, H. Housefly (Musca domestica) larvae powder, preventing oxidative stress injury via regulation of UCP4 and CyclinD1 and modulation of JNK and P38 signaling in APP/PS1 mice. Food Funct. 2019, 10, 235-243. [CrossRef] [PubMed]

24. Sun, T.; Yang, W.; Zhang, S.; Zhao, Z.; He, G.; Yang, D. Composition analysis of Musca Domestica pupa and preparation of antioxidant peptides. Feed Ind. 2019, 40, 30-37.

25. Sila, A.; Bougatef, A. Antioxidant peptides from marine by-products: Isolation, identification and application in food systems. A review. J. Funct. Foods 2016, 21, 10-26. [CrossRef]

26. Pan, X.; Zhao, Y.Q.; Hu, F.Y.; Wang, B. Preparation and identification of antioxidant peptides from protein hydrolysate of skate (Raja porosa) cartilage. J. Funct. Foods 2016, 25, 220-230. [CrossRef]

27. Wong, F.C.; Xiao, J.; Ong, M.G.L.; Pang, M.J.; Wong, S.J.; Teh, L.K.; Chai, T.T. Identification and characterization of antioxidant peptides from hydrolysate of blue-spotted stingray and their stability against thermal, $\mathrm{pH}$ and simulated gastrointestinal digestion treatments. Food Chem. 2019, 271, 614-622. [CrossRef]

28. Park, S.Y.; Kim, Y.S.; Ahn, C.B.; Je, J.Y. Partial purification and identification of three antioxidant peptides with hepatoprotective effects from blue mussel (Mytilus edulis) hydrolysate by peptic hydrolysis. J. Funct. Foods 2016, 20, 88-95. [CrossRef]

29. Li, Z.; Wang, B.; Chi, C.; Gong, Y.; Luo, H.; Ding, G. Influence of average molecular weight on antioxidant and functional properties of cartilage collagen hydrolysates from Sphyrna lewini, Dasyatis akjei and Raja porosa. Food Res. Int. 2013, 51, 283-293. [CrossRef]

30. Liu, C.; Ren, D.; Li, J.; Fang, L.; Wang, J.; Liu, J.; Min, W. Cytoprotective effect and purification of novel antioxidant peptides from hazelnut (C. heterophylla Fisch) protein hydrolysates. J. Funct. Foods 2018, 42, 203-215. [CrossRef]

31. Kimata, J.; Shigeri, Y.; Yoshida, Y.; Niki, E.; Kinumi, T. Artificial oxidation of cysteine residues in peroxiredoxin 6 detected by two-dimensional gel electrophoresis and capillary liquid chromatography-electrospray mass spectrometry. Mass Spectrom. Lett. 2012, 3, 10-14. [CrossRef]

32. Sierra, H.; Cordova, M.; Chen, C.S.J.; Rajadhyaksha, M. Confocal imaging-guided laser ablation of basal cell carcinomas: An ex vivo study. J. Investig. Dermatol. 2015, 135, 612-615. [CrossRef] [PubMed]

33. Shu, C.W.; Cheng, N.L.; Chang, W.M.; Tseng, T.L.; Lai, Y.K. Transactivation of hsp70-1/2 in geldanamycin-treated human non-small cell lung cancer $\mathrm{H} 460$ cells: Involvement of intracellular calcium and protein kinase C. J. Cell. Biochem. 2005, 94, 1199-1209. [CrossRef] [PubMed]

34. Kuhla, B.; Kuhla, S.; Rudolph, P.E.; Albrecht, D.; Metges, C.C. Proteomics analysis of hypothalamic response to energy restriction in dairy cows. Proteomics 2007, 7, 3602-3617. [CrossRef] [PubMed]

35. Zou, T.B.; He, T.P.; Li, H.B.; Tang, H.W.; Xia, E.Q. The structure-activity relationship of the antioxidant peptides from natural proteins. Molecules 2016, 21, 72. [CrossRef] [PubMed]

36. Li, Y.; Yu, J. Research Progress in Structure-Activity Relationship of Bioactive Peptides. J. Med. Food 2014, 18, 147-156. [CrossRef]

37. Samaranayaka, A.G.P.; Li-Chan, E.C.Y. Food-derived peptidic antioxidants: A review of their production, assessment, and potential applications. J. Funct. Foods 2011, 3, 229-254. [CrossRef]

38. Lavrovsky, Y.; Chatterjee, B.; Clark, R.A.; Roy, A.K. Role of redox-regulated transcription factors in inflammation, aging and age-related diseases. Exp. Gerontol. 2000, 35, 521-532. [CrossRef]

39. Nielsen, P.M. Improved Method for Determining Protein Hydrolysis. J. Food Sci. 2001, 66, 642-646. [CrossRef]

40. Zhou, J.; Kong, L.; Fang, N.; Mao, B.; Ai, H. Synthesis and functional characterization of MAF-1A peptide derived from the larvae of housefly, musca domestica (Diptera: Muscidae). J. Med. Entomol. 2016, 53, 1467-1472. [CrossRef] 
41. Yarnpakdee, S.; Benjakul, S.; Kristinsson, H.G.; Kishimura, H. Antioxidant and sensory properties of protein hydrolysate derived from Nile tilapia (Oreochromis niloticus) by one- and two-step hydrolysis. J. Food Sci. Technol. 2015, 52, 3336-3349. [CrossRef] [PubMed]

42. Zhu, C.Z.; Zhang, W.G.; Kang, Z.L.; Zhou, G.H.; Xu, X.L. Stability of an antioxidant peptide extracted from Jinhua ham. Meat Sci. 2014, 96, 783-789. [CrossRef] [PubMed]

43. Zhang, Q.; Tong, X.; Li, Y.; Wang, H.; Wang, Z.; Qi, B.; Sui, X.; Jiang, L. Purification and Characterization of Antioxidant Peptides from Alcalase-Hydrolyzed Soybean (Glycine max L.) Hydrolysate and Their Cytoprotective Effects in Human Intestinal Caco-2 Cells. J. Agric. Food Chem. 2019, 67, 5772-5781. [CrossRef] [PubMed]

Sample Availability: Samples of the compounds are not available from the authors.

(C) 2019 by the authors. Licensee MDPI, Basel, Switzerland. This article is an open access article distributed under the terms and conditions of the Creative Commons Attribution (CC BY) license (http://creativecommons.org/licenses/by/4.0/). 